\title{
Sigur Rós's HeIma: An Icelandic Psychogeography
}

\author{
Transforming Cultures eJournal, \\ Vol. 4 No 1, April 2009 \\ http://epress.lib.uts.edu.au/journals/TfC
}

\section{Tony Mitchell ${ }^{1}$}

\section{Abstract}

This paper examines the sonic geography of the Icelandic ambient rock group Sigur Rós with particular reference to their documentary film Heima, which documents a tour the group made of remote places in their home country. Known for causing some people to faint or burst into tears during their concerts, Sigur Rós's music could be said to express sonically both the isolation of their Icelandic location and to induce a feeling of hermetic isolation in the listener through the climactic and melodic intensity of their sound. This is distinguished by lead guitarist Jónsi Birgisson's falsetto vocals and Gibson Les Paul guitar played through reverb with a well-resined cello bow, heavily amplified drums, and the use of various types of keyboards, including church organ, minimally emphatic bass, and an all-female string section called Anima who play instruments such as xylophone, celeste, a glass of water, a musical saw and a laptop. Singing both in Icelandic and an invented language called Hopelandic (vonlenska), Jónsi, who is gay and blind in one eye, channels a striking form of glossolalia in his vocals which links the group's music to ambient rock predecessors such as the Cocteau Twins and Dead Can Dance. As Edward D. Miller has stated, 'Glossolalia reveals the tension between voice and signification, and exposes the communicativeness of sounds itself. The casual listener to Sigur Rós easily becomes an involved one. S/he is listening to made up words and in accepting the meaning of their arrangement in a melody, imagines what the lyrics might mean. This dual dynamic creates a strong emotional correspondence between the band and its listener' (2003: 8). The group acknowledges a strong degree of Icelandic animism in their music - they have referred to 'the presence of mortality' in the Icelandic landscape, and their links to stories, sagas, magic and ritual in a remote country where 'the majority of the population believes in elves and power spots ... the invisible world is always with us' (Young 2001:33). In their music they create geomorphic soundscapes which transport the active listener into an imaginary world. As bass player Georg Holm, who is demophobic, has stated, 'we provide the colours and the frame and you paint the picture' (Zuel 2005). This paper mobilises Barthes' 'jouissance', Michael Bull's work on personal stereos, and Daniel Grimley's work on music and Nordic identity along with various notions of musical affect to discuss relations between Sigur Rós's music, arctic landscape and its resonances outside Scandinavia.

\footnotetext{
${ }^{1}$ Tony Mitchell teaches at the University of Technology, Sydney.
} 


\section{Music, Landscape and Psychogeography}

As Bruce Chatwin once noted, music is often able to provide us with "a memory bank for finding one's way about the world" (1988: 120). Music can evoke or recreate places, spaces, localities and occasions, as well as providing biographical cartographies and metaphorical orientation guides, along with affective embodiments of identity, home and belonging. In less socially and culturally integrated circumstances - exile, migration, stagnation or enforced labour, for example - it may also express a sense of conflict, displacement, isolation and alienation. The Animals' 1965 song "We've Got to Get Out of This Place”, written by Barry Mann and Cynthia Weil, adapted by the band to refer to their northern British home town of Newcastle, and later adopted by the US armed forces in Vietnam, and reprised in numerous contexts of hardship ever since, including by coalition forces in Iraq, is one of many examples of a negative evocation of place. ${ }^{2}$ Song lyrics are the most obvious way of connecting music to place, in both local and global contexts, and the innumerable examples of the use of place names in blues and folk music can be seen in relation to Mike Crang's observations in Cultural Geography:

The geography of music has often contrasted local and universal, rooted and rootless. It has thus been led into a search for regional folk types - the mapping of styles and influences ... a quest to find the "authentic" local style and songs (1998:90).

Crang suggests this quest for an "authentic" local in music can often be counterproductive, involving nostalgic and wishful forms of re-invention, and he outlines a more oblique and affective way of reading geography through music: "The geography of music may also be traced through the spaces of listening and performance, the creation of what one might call sonoric landscapes". He employs the term "spaces of affect" to refer to "shared reactions to music", noting that "It is not just a matter of associating bands with places, or even observational lyrics about places, but also the way music forms spaces for people" (Ibid., 92-93). This gestures towards a more open, poetic way of reading place, community and identity through music, or situating music as "embedded in a locale" (Ibid. 91). In an article about the "Canterbury sound" in the UK associated with the music of the Soft Machine, Caravan and their numerous genealogies, Andy Bennett notes that “The fans inscribe Canterbury's streets, pubs,

\footnotetext{
${ }^{2}$ The song title was also appropriated by Lawrence Grossberg for a book which deals with, among other things, with mapping popular culture (Grossberg 1992).
} 
venues and other urban spaces with their own fictive interpretations" (Bennett 2004:209) which are often add odds with those of the musicians themselves. Nonetheless a Canterbury-based musical mythology has endured through numerous websites, along with those of numerous other places associated with music scenes throughout music history, which have strong affinities to the "imaginative geography" Edward Said defined as the basis of Orientalist thought (Said 1978: 49-73). It is the positive attributes of this notion of the recreation of an imaginary cartography through music that I want to explore here.

In terms of indigenous musical sonoric geographies, Steven Feld has used the term "song paths" to describe musical practices involving a collective "conceptualisation of place as a cartography of human song and lament" among the Kaluli people of Bosavi in the southern Highland rainforests of Papua New Guinea. Here "vocal and musical instrumental sounds are inspired by, modelled upon, and performed with ... environmental sounds" such as water, insects and birdsong (Feld 2001:193). Feld mobilises Edward Casey's term "place memory" (2001:201) as a key aspect of indigenous forms of musical production, and in constructing "place as evocative embodiment" (202), in songs, chants and musical compositions which often refer to place names and journeys. He also cites Melvin Dixon's writing on African-American literature, where geographical terrain ranging from underground to mountains and rivers are interpreted through music to the effect that "Music creates a landscape, defines a space and territory the singer and protagonist can claim" (2001:203). And landscape itself, both urban and rural, as Anne Winston Spirn has explored in depth, can be read as language, with its own stories, meanings, grammar and syntax:

Humans interpret landscape signs and elaborate upon them, reading meanings in to tell stories. The closer invented meanings are to significant, inherent qualities the more they draw from embodied knowledge rather than disembodied, abstract ideas ... Invented meanings remote from experience depend entirely on the mind's imagining (Spirn 1998:32).

As a way of reading landscape and place, music can arguably function as a form of mediation between knowledge, embodied or otherwise, and the imagination. The term "psychogeography" has been used increasingly to describe a mode of writing which usually involves urban geography, often related to Walter Benjamin's notion of the flâneur, and embodying what Sukhdev Sandhu, himself a London psychogeographer, 
reviewing the 2006 book Psychogeography by Merlin Coverley, defines as

a poetics of perambulation ... a particular kind of mental and imaginative mapping, one often associated with writers such as Peter Ackroyd and Iain Sinclair ... It involves moving about the city ... and being attentive not only to new buildings and architectures, but to the ghosts of previous urban cartographers and visionaries (2006).

Coverley's book, which was also reviewed in the British national press by British ambient dub musician Jah Wobble, another psychogeographer and urban walker $(2006)^{3}$, assembles an exclusively British and French literary tradition of psychogeography drawing on the origins of the concept as it was developed as a means of reading identity through the emotional overtones of place by geographer William G. Niederland and Guy Debord and the Situationists in the 1950s (Coverely 2006, Self 2007).

As well as being an increasingly mainstream literary and artistic practice, or even a "London brand" as Sinclair has argued (in Covereley 2006: 122), Sandhu suggests there is an important musical dimension to psychogeography, citing Barry Adamson's 1989 imaginary film soundtrack album Moss Side Story and Pulp's 1992 B-side "Sheffield Sex City" as English provincial examples. One might add popular songs such as Jacques Brel's "Le plat pays" ('The Flat Country', 1962) or the Kinks' "Waterloo Sunset" (1967) among innumerable other examples of songs in which the lyrics are the prime carriers of a sense of place. It goes without saying that places and landscapes have been a major inspiration for a plethora of songs and compositions throughout Western musical history, from Beethoven to the British pastoral tradition of Vaughan Williams and others, to the expressions of landscape in Grieg, Sibelius and the Nordic classical tradition that Daniel Grimley has analysed (Grimley 2006, Knight 2006).

"Psychogeographic" onstructions of musical animism, both urban and rural, are often connected with environmentalism, or what Feld has referred to as "acoustic ecology" (2001:194). Winter Music: Composing the North, by the Alaska-based composer and environmental activist John Luther Adams (2004), is a series of reflections on the relation of the composer's work to the contours of the far northern landscape he lives in. It is a book which, Grimley suggests,

\footnotetext{
${ }^{3}$ Unfortunately Wobble refrained from making any musical references in his review.
} 
asks whether there are any paradigmatic structures or forms which define landscape across a range of different media (equivalent to a basic "grammar and syntax" of landscape). Is the musical representation of landscape only contextually defined, or can it be accorded a more abstract spiritual quality? (Grimley 2005a:669).

Empirical experiments have suggested that listeners tend to associate slow, gradually evolving music with rural landscapes, but there is never any guarantee that specific places as sources of inspiration for composers of instrumental music will necessarily be communicated to audiences. Nonetheless, with foreknowledge of the composer's or musician's sonic evocations of particular places, listeners can arguably recontextualise those places in imaginary responses to the music, and mobilise music as a form of pyschogeographic reading.

\section{The Idea of North}

Nordic and Arctic landscapes have had a particularly strong influence on musical compositions, from Williams' Antarctica symphony (and numerous other works composed about Antarctica, from Peter Maxwell Davies to the Australian jazz composer John Elder) to saxophonoist Jan Garbarek's Norwegian jazzscapes, and the whimsically glossalalic cadences of Icelandic pop singer Björk. In an essay about the “multi-hued northern aura" (2007: 29) of German producer Manfred Eicher's jazz and new music label ECM (Edition of Contemporary Music), Michael Tucker invokes Glenn Gould's multi-layered 1960s radio travelogue The Idea of North, which explores the isolation and solitude of the far northern regions of his native Canada and its conduciveness to music making, making particular reference to Sibelius. But as the Scottish-born geographer Peter Davidson indicates in his book The Idea of North: Topographics, which deals with artistic, literary and cinematic imaginings of northern regions as well as histories and topographies, the "idea of north" is, of course, a highly relative concept depending on the location of the perceiver. For Australians the idea of north may involve thinking no further than far north Queensland or Darwin, whose contrasts with the Artic Circle could not be more extreme; nonetheless Davidson's book has a prominently northern hemisphere focus on the affective aesthetics of Scandinavia 
as well as northern England and Scotland, Japan and China. Clearly remoteness, isolation, wide open spaces, snow, mountains, tundra and extreme periods of cold and darkness are paramount in northern hemisphere conceptions of north.

Applying Glenn Gould's notions of north as a zone of musical creativity to the prominent Scandinavian jazz musicians who have recorded on ECM, such as saxophonist Garbarek, double bassist Arild Anderson, drummer Jon Christensen, pianist Bobo Stenson and trumpeters Nils Petter Molvaer and Arve Henriksen, guitarist Terje Rypdal, and percussionist Edward Vesala, among others, Tucker suggests three aspects to the northern topography of the label. The first is an experience of space, time and light capable of evoking the sublime, expressed in "a broad and spacious approach to matters of tone and texture, rhythm and phrasing"; the second a philosophical and existential quest for meaning which "revivifies and develops pre-Christian or pantheistic sources of spirituality"; and the third a sense of what Finnish poet Anselm Hollo has called "the solid human realness of the Nordic" combined with the expressions of an "intensive visionary mind" (2007:32-34). These aspects, Tucker argues, are contained in the music's recourse to Nordic folk music traditions as well as through improvisation and a prevalent sense of melancholy, often using minor keys, and what pianist Jon Balke refers to as "the need for a space of reflection after a statement has been made “ (in Lake and Griffths 2007:38). Landscape is sometimes directly embodied in the music, especially in a recording such as Garbarek's 1977 album Dis, in which his saxophones and wood flute create a dialogue with a drone-like Aeolian wind harp built by Sverre Larssen, "reacting directly to the air stream and creating this sound image of the wind". The harp was recorded on the coast of Southern Norway, where it caught "unending gusts of wind coming in from the north sea" (Garbarek 1977). A 2008 recording by Norwegian trumpeter Arve Henriksen, a musician who plays in the avantgarde jazz group Supersilent and is strongly influenced by the ambient tones of Jon Hassel and Brian Eno, is entitled Cartography, and incorporates his readings of landscape and travel diaries by British experimental musician David Sylvian. It prompted Guardian jazz critic John L. Waters to ponder on its imaginary topography and the Nordic shift in contemporary jazz:

Some people are sceptical of claims that jazz's centre of gravity is now nearer to the Arctic than to the Mississippi delta. The Norwegian scene may be amazing, but surely it's too small to warrant redrawing the jazz map? Yet small 
movements can produce big changes: look at Swiss modernism, dada or AfroCuban music. Norwegian trumpeter Arve Henriksen is a brilliant, versatile improviser whose language spans electronica, jazz and contemporary classical, and the best moments on this new album transport the listener to a land beyond borders of country or genre (2008).

In his book Is Jazz Dead? (or has it moved to a new address), Stuart Nicholson suggests that the "Nordic Tone" of Scandinavian jazz, along with other developments in European jazz, have displaced the USA in relation to the centrality of experimental tendencies in contemporary jazz. He cites the "mountain jazz" (2005:221) of Garbarek as representing "ordered calm in the often frantic world of jazz, projecting the stark imagery of nature in the frozen north" $(2005: 207)$ as a prominent example. Nicholson argues

[the] Nordic tone avoids the "external," the patterns, the favourite licks, the quotations, and extroverted technical display of much of contemporary jazz, and instead zooms in close to deeply felt melody, exposing tone, space and intensity (2005:198).

As an example of the distinctive sense of space and locality in the "Nordic tone", Nicholson quotes Norwegian pianist Tord Gustavsen, who states:

Even though we live in a very globalised world and Norway is very much part of that, it still shapes me differently than it would living in New York or London ... the melancholy and reflective moods, associated with Nordic music ... (and) "spacious open music" ... (2005:217)

These melancholic, pantheistic, animistic, rural and folkloric elements expressed through the spacious, melodic intensities of Scandinavian jazz are arguably also present in other forms of Scandinavian music. Nicola Dibben has argued that Björk's Icelandic nationality has been "used both as an explanation of what are seen as her eccentricities, and as an explanation for, and metaphor for the extremes of her identity (the fire and ice of her home country)" (Dibben 2006:2). Dibben also cites the singer's use of a semiotic geographical metaphor to explain subjective ways of reading the lyrics of her songs and the images associated with them in terms of a David Attenborough-like guide to a cave full of emotions, where "the words and the images are more like signposts, a tool to describe the signs" (Ibid.174). In an analysis of Björk"s track "Hidden Place" from her 2001 album Vespertine, Grimley explores the semiotic connections in the song's multi- 
layered construction between electroacoustic music, hyperreality and Nordic landscape:

this sense of "spaciousness" in popular music, most powerfully presented as a rejection of or escape from modern urban society, can be created through a number of specific musical devices, including the use of a wide but sparsely filled registral space, a high degree of electronic reverberation, the apparent lack of musical movement so as to suggest an unchanging continuity, and the divergence between fast, intricate surface movement and a slow underlying rate of harmonic change. "Hidden Place", as analysis has shown, exploits all of these devices in its evocation of Nordic landscape, albeit one that is interiorized (and self-consciously imaginary) (Grimley 2005b: 48).

These spatial musical properties of "Hidden Place", Grimley suggests, without needing to make reference to the lyrics of the song, do not merely amount to an expression of Icelandic national identity and/or locality, but a more generic poetics of Nordic landscape. Grimley's analyses of music's evocations of landscape in a Nordic context can be linked to a body of existing writing on music and place by authors such as George Lipsitz and Sara Cohen, among others. Music can be heard as a way of expressing the tones, moods, atmospheres and force fields of landscapes and cityscapes through mimetic means, where purely musical forms, dynamics, structures and movement both mirror and embody the contours of the landscape. Grimley, drawing on Smalley's notion that electroacoustic music is audiovisual, suggests attention to the correlation between visual and auditory modes of perception can prompt a deeper understanding and appreciation of actual sound events. Smalley defines the vision field as one that

embraces both kinetic and static phenomena. For example, the textural design of textiles or rock formations could easily form part of a listener's indicative reference-bank (Smalley1992: 520).

It defines musical events whose timbral (or spectomorphological, to use Smalley's term) profile carries strong associative links with particular visual images (whose qualities include shape, colour, texture, depth or lines of perspective), and maintains that such links are a meaningful part of the way in which we listen to music (Grimley 2005: 44).

One Nordic example which illustrates Grimley's observations about "spectomorphological" musical events is Swedish nyckelharpa player Johan Hedin, 
whose 1998 album Angel Archipelago has track titles such as "The Shore", "Skerries", "Burn-Beaten Land", "The City" and "High Sea". Recorded without overdubs or noise reduction, and with accompaniment by bass, percussion, saxophones, violin, cello, accordion, lute, "sonics" and vocals, the music evokes the texture of the fjords shown on the cover of the album. The nyckelharpa is a folk instrument which is played with a bow like a violin, has keys like a hurdy-gurdy, and resonance strings like a viola d'amore. Its origins date back to the Middle Ages, and it has a harsh, Celtic resonance suggestive of Medieval music. As Hedin has stated of his country of origin:

this is the land of the nyckelharpa, the land where trees are transformed into this instrument, and the bows are made from horsehair since time immemorial. This is truly an instrument which comes from its own country, creating its own sound (Hedin 1998).

As Lundberg, Malm and Ronström have pointed out, the nyckelharpa almost became extinct in Europe outside the Uppland region of Sweden in the 1960s, but a 1967 dissertation by Jan Ling on the instrument spearheaded its revival, to the extent that there were an estimated 10,000 musicians playing the instrument by 2003 . It has since been nominated by the Swedish Environmental Party as the Swedish national instrument, like the kantele, a Finnish plucked string instrument resembling a koto, and the violin-like hardingfele in Norway (2003:241). It was also "just exotic enough" (2003: 233) to catch the world music boom of the 1980s, and was subsequently popularised locally by the Swedish folk-rock group Nordman, who formed in 1993.

Other forms of Nordic music are also directly embodied in the landscape. Norwegian percussionist Terje Isungset's 2002 album Iceman Is, a collection of vocal and instrumental tracks with titles such as "Blue", "Frozen", "Water" and "In Glacier", creates a Nordic soundscape which directly evokes audiovisual modes of perception. Described by Isungset as the "world's first ice recording ever", it employs speciallyconstructed musical instruments such as the ice harp, ice horns, ice trumpets, ice percussion and iceophone, which were recorded at the Ice Hotel in Sweden in a studio and control room built of ice and snow which is "now somewhere in the north sea" (Isungset 2002). Also drawing on electronic sounds and featuring Arve Henriksen, the album's sonic palette sounds at times similar to the taonga puoro, pre-European Maori musical instruments built from flax, shells, bone and other raw material of the landscape 
on the other side of the world in Aotearoa/New Zealand, while managing to evoke directly expanses of arctic landscape both sonically and visually. As one blog reviewer has commented on Iceman Is and Isungset's two subsequent albums: "The overall sound is one of desolation, loneliness, and it's not hard to visualize white landscapes or month-long darkness" (http://isungset.blogspot.com/ ). Isungset, who embarked on the "World's first Ice Music tour" in January 2007, and was also involved in an Ice Music Festival in Norway in the same year, has also made music out of trees, rocks, metal and garbage, as well as a composition made up of sounds from an oil rig. Environmentallybased music of this kind, which expresses the textures of what Gould has referred to as "that incredible tapestry of tundra and taiga which constitutes the Arctic and Subarctic" (Gould 1967) in imaginary ways, is a fundamental aspect of the "Nordic tone".

[Watch a short clip regarding the icicle orchestra. Pioneering percussionist Terje Isungset plays instruments made from a 2500 year old glacier: http://www.guardian.co.uk/music/video/2008/nov/25/norway-ice-music-terje-isungset ]

\section{An Icelandic Musical Journey}

Grimley's and Smalley's observations suggest that we can see music as well as hearing it; not in any banal sense of colour, pictorial or mood associations, but through music's sonic evocation of a memory bank of images which may be urban or rural, depending on the textural qualities of the music. As Grimley states of Sibelius:

Landscape is as much a subjective as pictorial presence within Sibelius's music, and landscape processes offer a powerful analogy for the temporal lines of perspective that run through Sibelius's music. The intention is to shift the idea of landscape from the domain of reception to that of musical perception and signification (Grimley 2004:3).

These analogies between landscape and "temporal lines of perspective" could also be applied to the ambient post-rock music of Icelandic group Sigur Rós, which tends to build sound-pictures gradually and accumulatively in terms of slow tempos, sudden bursts of volume, generally simple dynamics and considerable intensity in a process which metaphorically evokes glacial shifts or the contours of craggy hills. "Atmospheric, ethereal, dreamlike and intense" (Eleizer 2006:18) are standard epithets deployed by music journalists to describe the group's music. 
Sigur Rós's music provides the listener or viewer with a sonic and visual expression of an Icelandic imaginary in which, as bass player Georg Holm has said: "we provide the colours and the frame and you paint the picture" (in Zuel 2005a:38). There are arguably aspects of synaesthesia involved in this process, in which sensory impressions of an Icelandic "sonic geography" becomes activated in the listener's imagination. As Zuel stated in a review of Sigur Rós's 2005 Sydney concert:

Some Sigur Rós songs drive through atmosphere as if expelled from giant lungs, tumbling loose items in their way. They begin with a draw of air in; expand to receive the layers of bowed guitar, keyboards, increasingly prominent bass and larger and larger drums, and then release all that energy and sound in wave after wave. They are powerful, thundering moments (Zuel 2005b.)

This gigantic metaphorical breath can be related to a comment keyboard player Georg Holm made:

If you think about it, music is only moving air. But when you're moving air, you can actually move people at the same time (in Jollett 2005).

The group's music forms an embodied soundscape, in which ambient atmospherics are expressed in a sonic process which Zuel compares with the Australian ambient composer/ musician David Bridie, who has drawn extensively on indigenous music from Papua-New Guinea, British ambient guitarist Robert Fripp, as well as rock groups Radiohead and the Cocteau Twins, the latter of which employs swirling soundscapes and glossolalic vocals similar to those of Sigur Rós. Comparisons are also sometimes made with Montreal-based post-rock collective Godspeed You Great Emperor, whose dark, brooding guitar-based soundscapes contain similar degrees of haunting abstraction, and post-rock guitar groups Mogwai and Explosions in the Sky.

\section{From Reykjavík, Iceland, to Newington, Sydney}

Sigur Rós"s "Untitled 9C" has started droning away - all it consists of is a pair of repeated, extended, low, deep notes which become quite hypnotic. It's a soft, low hum which invades the listener subliminally. You reach a point where you think you're ignoring it and it's faded into the background but it's still there, insisting on its presence. It could become irritating but it's also soothing. It's what Sigur Rós usually 
play through their sound system when they're setting up to perform. The set-up involves a gauze curtain covering the outdoor stage which is shrouded in darkness. I'm at the Great Escape - a music festival on "the rolling hills and historic bunkers of the Newington Armory, a riverfront haven in Sydney's Olympic Park" as the publicity brochure describes it. It is a former military base which is just opposite the Mulawa women's prison at Silverwater, reputedly the most violent jail in NSW, where "half the inmates are assaulted and almost one in five officers is attacked every year" (Wainwright 2002). A site of bleak isolation if ever there was one, but suffused by the humid heat of a Sydney summer afternoon. Later we pass the grey grim-walled exterior of Mulawa on our way back to Olympic Park station on the festival shuttle bus, relieved to be getting out of this place and not forced to stay here indefinitely like some of the inmates. Even the campers who are in for the whole three days of the festival are able to escape back to the normality of Sydney or other destinations at the end of it. Earlier in the day, Melbourne blues singer and slide guitarist Mia Dyson dedicates her searing lesbian prison song "Roll Me Out", based on stories she collected while performing in Deer Park women"s prison in Victoria, to the Mulawa inmates. Who probably couldn't hear her dedication - although one would like to think that the onslaught of music coming from the park opposite might have temporarily invaded their violent confinement. Not far away at Homebush in Western Sydney the festivities, joyrides, and country livestock displays of the Royal Easter Show, complete with kitsch souvenirs and angel haloes, are raging away.

Different places produce distinctively different sounds; as John Street has put it, "different cities, like different countries, make different noises" (1995:259). And the music of particular places provides an important means of reading these places; according to a quotation attributed to Confucius in Crossing the Bridge, Fatih Akin's 2005 film about music in Istanbul, "to understand the place, you have to listen to the music it plays" (Turan 2006).

Street has usefully broken down the relationship between music and locality into different discourses: industrial base, social experience, aesthetic perspective, political experience, community and scene, all of which arguably enmesh themselves even more intensely in isolated places, while at the same time still maintaining complex global connections (1995: 256-257). They are tightly intertwined in the case of Sigur Rós and 
their internationally known peers on the Reykavic indie and experimental music scene, starting with Björk, and working its way down through Múm, Kitchen Motors, GusGus and numerous others not so well known, and into films like Rekyavik 101, Cold Fever, Noi the Albino and Angels of the Universe (for whom Sigur Rós provided a couple of songs, one based on the music that is played in Icelandic national radio announcements of deaths and funerals). The Uni:Form label (the electronic wing of Thule Music, a dub-influenced minimal techno label who distributed Múm”s music) released a 2003 compilation of Icelandic ambient music, 42 More Things To Do in Zero Gravity, which assembles a number of electroacoustic tracks by entities such as Múm, Ruxpin, Krilli, Trabant, Thor and Worm is Green, some of whom have remixed Sigur Rós and each others' tracks, evoking a strongly collaborative ethos and suggesting an oblique far north association which is as enigmatic as it is consistent. "Thule" refers to Ultime Thule, the term used in Mediaeval geography to refer to Greenland, or sometimes Iceland, or any place beyond the borders of the known world.

Iceland's musical infrastructures seem disproportionately strong in relation to the country's sparse population; Ari Alexander Ergis Magnússon's 2005 music documentary Screaming Masterpiece, the subtitle of which is "A Thousand Years of Icelandic Popular Music", features Björk and Sigur Rós along with a number of less familiar Icelandic rock, pop, electronic and hip hop groups, such as Bang Gang, Mugison, Minus, Ghostigital, hip hop group Quareshi and Slowblow. Intertitles announce in its opening sequence, over music by Sigur Rós, that Iceland is "a country with a population of 300,000, with 90 music schools, 400 orchestras and marching bands, and an unknown number of rock bands". The film's promotional blurb links the music to the country's landscapes and seascapes: "The creeping glaciers, barren highland sands and dark raging seas full of ghosts form a backdrop to the raw energy of the music."

In an article about Sigur Rós in The Wire magazine in 2001, Rob Young commented on the strong networks and closely-knit infrastructure of independent music outlets in Reykavik, which contains half Iceland's population:

Iceland, and Reykavik in particular, harbours a music scene most European countries would kill for. A mutually supportive network of shop chains, each run independently - often by musicians themselves - who between them take care of 
distribution for all the labels that come in from the rest of the world, acting as clearing warehouses for major and independent labels, from EMI to Kranky. It also has its own music magazines and media, plus apparently countless record labels putting out unconventional sounds ... descend to the next circle and you'll find a raft of adventurous music and sound artists working mostly in collaborative ventures (2001:32).

This suggests there is a strong communal ethos of collaboration in isolation, and a sense of common purpose, particularly in connection with ambient electrocoustic musical production. Lefebvre's idea of "spaces of representation", which are opposed to the powerful, mainstream "representations of space" and "linked to the clandestine or underground side of social life, and also to art" (1991:362), seems appropriate here, in terms of a social, aesthetic and industrial milieu - to use a term mobilised by Peter Webb (2007) in relation to independent music networks.

\section{Globalising Icelandic Animism}

The pathway of Sigur Rós's international success as an Icelandic entity was obviously assisted by the success of Björk, who began in a similarly "underground" post-punk milieu in the 1980s of the Reykavik-based band the Sugarcubes and its predecessors. In both cases there have been inevitable constructions of stereotypes of enigmatic and elfin aspects of Icelandic exoticism in media reports (Björk as an "ice queen" among numerous other epithets, Sigur Rós posing for photographs in elongated beanies in craggy landscapes) which have worked to some extent to the musicians' advantage, despite their attempts to discredit them, partly by attaching themselves to Icelandic musical traditions. Sigur Rós's transference to an international arena was also assisted by being endorsed by cult British indie rock band Radiohead, who invited the band to tour with them, and declared them their favourite group, which brought them to the attention of a worldwide network of Radiohead fans. But they also achieved recognition largely on the affective impact of their music, and they remain a totally independent enterprise recording on their own small independent label which manages its own affairs, like an increasing number of independent musicians around the world who no longer have to rely on major labels for distribution or recognition. 


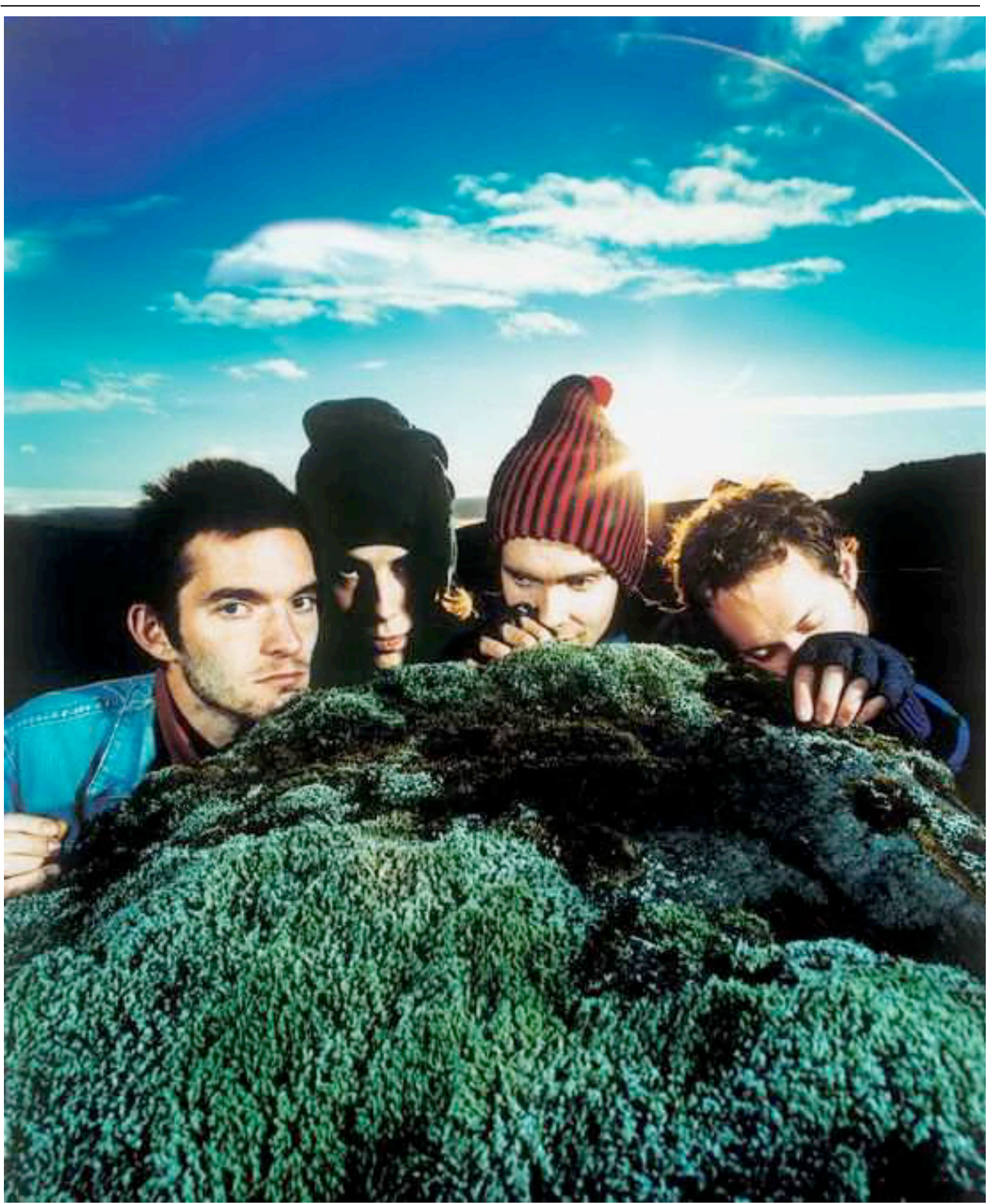

Sigur Rós pose in an Icelandic setting; from their website <http://www.sigurros.co.uk/>

The group's 2008 album með suð $i$ eyrum við spilum endalaust (with a buzz in our ears we play endlessly) was recorded in New York and has a much lighter, more poporiented dynamic than their previous, home-recorded albums, which have tended to be sombre and intense in their orientation. (Internationally renowned Icelandic crime writer Arnuldur Indridason has his lugubrious detective anti-hero Erlendur say at one point in his novel The Draining Lake, "Many Icelanders suffer serious depression, although 
most keep it well concealed" (2007:106)). Sigur Rós's Nordic isolation allows them to maintain their seclusion while transporting it to a global audience. Their wilfully independent, localised eccentricity has extended to recording their albums in a converted indoor swimming pool and a church in Reykavik and refusing to do an interview with influential British pop music weekly New Musical Express, instead, according to a Times interview with Sharon O'Connell, opting to grant an exclusive interview with the Shetland Seafood Journal, who have non-musical affinities with the band and their genius loci. ${ }^{4}$

As bass player Georg Holm, who on occasion plucks his strings with a drum stick, has stated:

We really just love to do our own thing, and do it the way we want to do it. We would never compromise it for anybody else. ... We're not anti-commercial. We want to spread our music as far as we can. Because we believe it can actually do something for people. So we want as many people to experience it as possible (in Jollett 2005).

Elsewhere Holm, who is demophobic, and fears crowds, a condition arguably exacerbated by live performances to large crowds and conducive to extreme isolation and disconnection, has said of the group's music, "I don't think Iceland is reflected in our music at all" (in Parker 2007), comparing this assumption with attempts to evoke Kylie Minogue as a musical representation of Australia. The key here is the term "reflect"; as Simon Frith has noted:

The issue is not how a particular piece of music or a performance reflects the people, but how it produces them, how it creates and constructs an experience $-\mathrm{a}$ musical experience, an aesthetic experience - that we can only make sense of by taking on both a collective and subjective identity ... we are drawn, haphazardly, into emotional alliances with the performers and with the performers' other fans (Frith 1996:109, 121)

Identity formation through music is an active, fluid process of production, creation and construction, not a question of mere reflection of nation state, place, landscape or environment. As Feld has stated, "there is still little [anthropological] work which takes the ecological-aesthetic interface beyond a low-level "reflectionist" paradigm"

\footnotetext{
${ }^{4}$ See interview with Sigur Ros here:

$<$ http://www.sigur-ros.co.uk/media/intervi/times1.php $>$.
} 
(2001:195). After reading R. Murray Shaffer's Tuning the World in the Bosavi rainforest, Feld himself embraced what he refers to as "Echo-Muse-Ecology" in which "A way of hearing the world comes from interacting with it, but it also has to do with appreciating it, imagining it as one's very own" (1994:3). Sigur Rós's music could be said to embody, express or evoke sonically both the remote isolation of their Icelandic location and to induce a feeling of hermetic isolation in the cartographic recomposition of the music by the listener through the climactic and melodic intensity of their sound. A metaphorical process, certainly, but one which arguably grounds the music in its country of origin, just as most of the group's music is recorded in particular Icelandic environments and localities which imprint themselves on to the music. As Feld notes, music is able to convey a sonic geography in which "the journey is completely in the listener's head ... Knowing where you are is knowing who you are” (2001: 205).

\section{Glossolalia and Nordic Textures}

The textures of Sigur Rós's music are distinguished by an other-worldly eeriness lent by lead guitarist Jónsi Birgisson's falsetto vocals, which he claims he uses because "I could tune my voice more and control it" (Sandall 2005). Unlike the voice of Anthony Hergarty, who expresses highly emotive and melodramatic registers through his castrato-like falsetto, but also through the highly suggestive transsexual qualities of his lyrics, Birgisson's voice has a particular grain which functions more like a tuned musical instrument, where the absence of comprehensible lyrics seals off the semantic register for the English-speaking listener. Singing both in Icelandic and an invented language called Hopelandic (vonlenska, a play on Islensku, Icelandic), he channels a striking form of androgynous glossolalia in his vocals which link the group's music to ambient rock predecessors such as the Cocteau Twins and Dead Can Dance. In an essay on the use of glossolalia in Sigur Rós's vocals, Edward D. Miller has suggested it generates affect and involvement:

Glossolalia reveals the tension between voice and signification, and exposes the communicativeness of sounds itself. The casual listener to Sigur Rós easily becomes an involved one. S/he is listening to made up words and in accepting the meaning of their arrangement in a melody, imagines what the lyrics might mean. This dual dynamic creates a strong emotional correspondence between the band and its listener (2003: 8). 
This argument, similar to Dibben's in relation to the affective bond between Björk and her audience, suggests the listener's imagination creates a sense of involved narrative, meaning and locality. The embodied singing voice can convey what Barthes has called an "erotic relation" (1977:299) with the listener, unimpeded by semantic meaning, a purely sonic, semantically liberated, melismatic experience which exposes all the intricacies, subtleties and beauties of the grain of the voice in its "mother tongue". Birgisson has likened glossolalia to the way a song is created before lyrics are written to it. Writing in the Guardian, Alexis Petridis notes:

You need a working knowledge of north Germanic phonology to even contemplate pronouncing [Sigur Rós'] song titles, which arrive in a blaze of diacritics, ligatures and voiced dental fricatives. That's when they arrive at all: their 2002 album had two brackets instead of a name and dispensed with a track listing in favour of a tracing paper booklet upon which fans were invited to draw their interpretations of the music (20007:2).

Language and the semantic meaning of lyrics are engulfed by the sensory impact of the evolving, quasi-sculptural sheets of sound, even if English translations of some of the lyrics reveal an often surreal, poetic dimension which complements the imaginary perspectives opened up by the music.

Simon Reynolds has written about the Cocteau Twins in terms of what he has referred to as "oceanic rock":

music ... attracted to expanses (the sky, the sea, the desert, the tundra) ... which wants to liberate itself from the confines of the self, time and the real world. This rock is an attempt to rediscover lost innocence and peace. It's hypnotic, and narcotic, a fall-back into the bliss-ful continuum of unconsciousness (1990:127).

While this description could be similarly applied to the abstract textures and sustained tranches of music Sigur Rós produces, it is arguable that their strong sense of emplacement, even within "expanses", together with their use of their native language, operate in a much more situated context, even as it evokes the unconscious and dreams. Reynolds has also compared the Cocteau Twins' lullaby-like use of glossolalia to French feminist theorist Hélène Cixous' pre-Oedipal écriture feminine, where "they imagine song that comes before language or grammar" (1990:130). He draws useful analogies with the ECM label, and Jan Garbarek's “tundra-at-dawn watercolours", 
although he suggests that the music of ECM expresses "a sense of benign space; space that isn't demarcated or geographically structured" (1990:134) in contrast to the more situated idea of a "Nordic tone" expressed earlier. Space is clearly an important aspect of this music, but it is also arguably a space that is imbued with a strong sense of what John Luther Adams has called "sonic geography": "a region that lies somewhere between place and culture, between human imagination and the world around us" (2004).

Birgisson also plays a Gibson Les Paul guitar through reverb with a well-resined cello bow, a process which he has described as follows:

With a bow you can get loads and loads of overtones so it's about how you handle them. It's like you're riding a really mad horse and you're trying to tame it" (2006 sigur-ros.co.uk 60).

Reference is frequently made in the band's publicity that Birgisson is gay and blind in one eye, an emphasis on his "othered" musical persona which distance him from the usual stock associations between lead guitar solos and expressions of masculinity, as Peter Elsdon has commented:

a crucial part of Birgisson's guitar sound is that the distortion isn't entirely under control, something again quite at odds with virtuosic notion of the solo in rock. And so these dissonances and tensions rip into the standard association of the guitar solo with the heroic and the masculine - this is a mode of playing which is not a standard performance of masculinity (Elsdon 2007).

Elsdon argues that this degree of displacement and uncertainty is conducive to "embodied listening" in response to the group's music. The bowed guitar is becoming increasingly common in rock groups, but was arguably first popularised in spectacular form in live performance and in the studio by Led Zeppelin guitarist Jimmy page in the late 1960s, on songs such as "Dazed and Confused". 5 More visually spectacular than the more compact EBow (Energy bow), a battery-powered electronic guitar pick which produces string, horn and distortion effects from an electric guitar, and was developed in 1976, use of a violin or cello bow has a strong visual as well as sonic dimension, and also arguably has visual and sonic associations with the use of bowed instruments in

\footnotetext{
${ }^{5}$ My own memories of seeing Led Zeppelin live in 1972 certainly support Elsdon"s idea of "embodied listening", due as much as anything else to the degree of volume Page produced from the technique.
} 
Nordic folk music. Sigur Rós also use heavily amplified tuned percussion, and various types of keyboards, including church organ and a Yamaha portasound sampler, as well as an emphatically pounding bass playing strung-out single notes which often carry the chord sequences used in individual songs. They have also employed an all-female string section called Animamina (later shortened to Amiina) who play instruments such as violin, cello, xylophone, celeste, a glass of water, a musical saw and a laptop. Amiina have released their own album and played as Sigur Rós's support act.

In terms of their aesthetic perspective, Sigur Rós acknowledge a strong degree of Icelandic animism in their music - they have referred to "the presence of mortality" in the Icelandic landscape, and their connection to stories, sagas, magic and ritual in a remote country where as Angels of the Universe film composer Hilmar Hilmarrson, with whom the group have collaborated on instrumental and film projects, has said "the majority of the population believes in elves and power spots ... the invisible world is always with us” (in Young 2001:33). One of Sigur Rós's earlier songs is entitled "Starálfur" (Staring Elf) and was British music weekly New Musical Express's single of the week in September 1999 as well as the group's first release to be distributed outside Iceland, resulting in a flurry of publicity in the UK. In the same year their album Agaetis Byrjun was declared Iceland's best album of the 20th century, so they are clearly a source of national pride in their home country. The spectomorphological evocations of Nordic landscape Grimley attributes to Björk are arguably just as strongly present in Sigur Rós"s more heavily ambient music.

\section{Heima}

In September 2007 Sigur Rós released Heima, Icelandic for "at home", or "homeland", a documentary film directed by Dean DeBois, which was filmed during an impromptu two-week long free tour of previously unannounced concerts they performed around the country after their 2006 world tour, visiting 16 different locations with a cast and crew of some 40 people. Playing venues that varied from an abandoned herring oil tank in Djupavik, a deserted fishing village in the far west of Iceland with a present day population of 2 people, to national parks, small community halls, icescapes, ghost towns, country tearooms and art shrines, the tour culminated in a triumphant homecoming concert performed to 25,000 people in Reykjavík, which was the largest 
gig of their career and the largest concert in Icelandic history. Highlights of the film include a performance at a borrablot feast - a mid-winter celebration held in February to honour the weather god Porri - held in Kirkjuboejarklaustur with traditional Icelandic poet Steindor Andersen, an exponent of "rimur" or rhyme, an ancient chanting style of Icelandic folk music, with whom the group have recorded. Also shown are a performance with a choir, an appearance by an oompa-ing village brass band who march across the outdoor stage and up the street, an encounter with a builder of marimbas and vibraphones made from slate stone taken from the Icelandic countryside as well as old rhubarb stalks, and an all-acoustic set performed in the wilderness at a protest camp at Snaefellsskala on the site of a hydro-electric dam designed to run an aluminium smelting plant. As the group note in interviews in the film, the idea was one of "giving back" what they owed to the people of Iceland, and "joining the soul of the Icelandic public". To the group it feels "like being on trial", since most of the audiences they played to were casual, curious and unfamiliar with the group's music. In the film members of the group ruminate on the importance of space in both personal life and in the land in Iceland, which they claim is "in our souls"; they also refer to Iceland as "a safe haven [where] we're left on out own". Keyboard player Kjartan Sveinsson has indicated how the tour generated a sense of belonging and community among audiences:

In the countryside it maybe made people a bit curious, so you had all ages grandparents, grandchildren and all of that - and a lot of them probably came just out of curiosity, not because they like the music necessarily. Just something going on in their hometown or near their hometown (Heima 2007).

As a psychogeographic journey, the film's remote, rural settings often evoke a solemn, ceremonial intensity which combines the curious and engaged faces of audiences and the varieties of landscape with a slow build to a climax which mirrors the hymn-like structure of the group's music, culminating in a flurry of red kites flying in the sky over Reykjavík. At once a travelogue, a cartography of Iceland and a music documentary, the film's gravitas provides a powerful antidote to the increasing use of the group's music in television commercials in the UK, as well as background music to such events as sporting competitions and The X Factor. James Hepokoski's suggestion that Sibelius "attempted through the processes of music to work his way back into the earth, water and sky to unlock the essential animating forces believed to lie therein" (in Grimley 
2004:116) might also be applied to Sigur Rós"s Heima in the way in which they inhabit the different contours of the country through their musical performances, as well as making an ecological statement in performing acoustically on the dam site.

[Watch a clip of the Heima trailer here:

$<\mathrm{http}$ ://au.youtube.com/watch?v=KpQ6m2Qf918\&NR=1> ]

\section{Dusk Over Homebush}

Hearsay has it that people have suddenly burst into tears, fainted or started laughing hysterically during Sigur Rós concerts, and that members of the group have had "mental collapses" backstage. As keyboard player Kjartan Sveinsson put it: "there have been times when one of us started crying for no reason, or started shaking ... Or onstage, someone's equipment is smashed up " (Eliezer 2006).

In his review of the band's 2005 Enmore Theatre concert in Sydney, Bernard Zuel described their music as a

cascading storm of sound ... something intangible and intoxicating that lifts you so you aren't sitting in a hard chair in an old inner-city theatre anymore but standing in some big-sky, crater-marked landscape where everything - colours, textures, smells - is heightened and wondrous (2005b).

This translation of the transportation and transformation of consciousness involved in experiencing Sigur Rós's music manages to convey a sense of the process by which the listener is enveloped and displaced without resorting to the standard clichéd epithet used by Anglophone popular music fans everywhere, "awesome", although for once it seems appropriate. One of my students wrote an assignment about her experience at the Enmore concert, during which she passed out as a result of her being emotionally and physically overwhelmed by the music, thereby proving the hearsay. The music seems to act like a drug, stimulating a state of consciousness arguably similar to the effects of the "magic glaze" of hashish as described by Baudelaire:

Sounds are clad in colour, and colour contains a certain music ... musical notes become numbers ... analogies attack, pervade, and overcome the mind .. and assume an unaccustomed vividness (1971:65). 
Silhouettes appear through the gauze curtain on stage. First Aniima appear and take up positions upstage with their violins, xylophones, celestes, etc., then the four male protagonists drift on. In almost total darkness, they start with "Takk", the short title track of their 2005 album. It means "Thanks" in Icelandic and starts with a soft sustained keyboard note which builds into a drone, as it slowly expands into a chord with repeated harmonic variations. When the bass kicks in chills go down my spine, augmented by the xylophone melody and the soft falsetto glossolalia as we move directly into "Glosoli" (Sun's Glow). The volume is almost frightening but the tempo is still slow, with the xylophone and repetitive drum sustaining a slow, chugging but soft, gentle rhythm.

Grainy black and white photos of landscapes and other objects are projected behind the band and as the sound builds slowly to a crescendo and Birgisson's arco guitar kicks in, the curtain peels back to reveal the group performing, no longer in silhouette. It's a magic moment, and right on cue fireworks appear in the sky above the Easter Show, far enough away to illuminate events without disrupting the sonic experience as the group segues into "Hoppipola" (Jumping Puddles), with its tinkling piano riff and lush orchestral fills with brass predominating.

There's quite a strong gay presence in the audience here - the guy in front of me is kissing and hugging all his male friends and handing out cigarettes to them, and several people around me are already "going off". And it's by no means music you can dance to, at the best you can sway sinuously and let the force of the thick orchestral wash of "Saeglopur" (Lost at Sea") and the pounding drums and soaring voice envelop you; some bits are so quiet and slow you barely register them - one track on "Takk" is called "So Quietly". But the flashing stage lighting and the visual projections compensate, and you can simply lose yourself in the sheer sonic power of the crescendos on tracks like "Milano".

\section{Geomorphic Music}

A lot of Sigur Rós's songs directly evoke weather and landscape, both day and night. One track on their album ágatis byrjun translates as "Good Weather for Airstrikes". Their website is called "18 Seconds before Sunrise", after a track from their 1997 album 
Von, and contains tracks entitled "Dawn" and "Sun of the Sea". Another track, "Alafoss", is named after the location of the band's studio. Their music hums with emplacement, and their music videos are suffused with Icelandic landscapes, especially "Glosoli", with its extraordinary visual and sonic crescendo. In the video, a gang of feral children led by a drummer boy in a sheepskin jacket ascend and then appear to fly off a cliff Peter Pan-style, (or lemming-like), but it is not revealed whether the youngest boy who is the last to join the group takes off or sinks as the camera pans away to the horizon. The clip was made by Stefan Arni and Siggi Kinski, formerly of the Kitchen Motors collective, and has a climactic intensity and a powerful sense of evocation of mountainous Icelandic landscape. It also conveys a sense of submission to an unconscious force which appears to animate from the mountainscape.

[Watch a clip of Glosoli here: <http://au.youtube.com/watch?v=doc1eqstMQQ> ]

In his spectrographic analysis of the climax in the song's final crescendo, which involves "a massive opening out of the frequency range of the recording", in combination with the video's dramatic climax, Elsdon notes:

In the video, the rush along the cliff-top to throw oneself off and then to fly, is about as intense a physical experience as one can imagine - and it's counterpointed by a musical code which is associated with a similarly heightened physical behaviour. An embodied reading of "Glosoli" might then understand this thrash section as coding a certain kind of physical response - it's a kind of sensory explosion articulated through the mix, through musical texture, through physical codes and through the video (Elsdon 2007).

The video "Svefn g englar" (Sleepwalkers) begins with a series of quotations from Nietzsche, Laurence Durrell, Tolstoy, Hugo, Plato, Carlyle, Leonard Bernstein and others about the power of music to affirm loneliness, soul and emotion, to express the inexpressible, to "paint pictures on silence", and to evoke the heart of nature, as well as the unnameable, unknowable and the infinite. This appears as a series of inscriptions of the group's musical philosophies, as well as confirming their grounding in evocations of Nordic landscape. It is followed by a slow motion sequence in which a group of Downe syndrome children and adults dressed in angel costumes dance in a grassy landscape.

[Watch a clip of Sven-g-englar here: $<$ http://au.youtube.com/watch?v=zQ5Grncdjlc $>$ ] 
Both clips express a powerful combination of "northern gothic" and "nordic tone" which is present throughout much of the group's music, and strongly linked to a sense of isolation. Like the personal stereo users Michael Bull discusses in his book Sounding Out the City, Sigur Rós's audiences and embodied listeners "move in public isolation but are not alone in their mediated flights of the imagination. Users are never "alone" as theirs is a more intimate yet more "isolated" form of company" (2000:146). Bull also suggests that

Music increasingly fills the gap left by the absence of any meaningful sense of the experienced social ... Music becomes a substitute for community, warmth and social contact (2000:129).

Standing in the middle of a field among an audience of several thousand people moving sinuously, watching and listening to Sigur Rós, it is difficult to disagree with this. We seem meditative and secluded, but also bound together in an imaginary space where the sonic geography of the music articulates an imaginary cartography of a remote place on the other side of the world.

\section{Bibliography}

Adams, J. L. (2004), Winter Music: Composing the North, Middletown, Connecticut, Wesleyan University Press.

Barthes, R. (1977/1990) "The Grain of the Voice" in Simon Frith and Andrew Goodwin (eds), On Record : Rock, Pop and the Written Word, London: Routledge.

Bennett, A. (2004) "New Tales from Canterbury: The Making of a Virtual Scene", in Music Scenes: Local, Translocal and Virtual, Nashville: Vanderbilt University Press.

Bull, M. (2000), Sounding Out the City: Personal Stereos and the Management of Everyday Life, Oxford: Berg.

Buttimer, A. (2006) Review of Davidson, Peter, Idea of North, The. H-Hist-Geog, HNet Reviews, February <http://www.h-net.org/reviews/showrev.php?id=11399> (accessed 16 October 2008).

Casey, E. (1987), Remembering: A Phenomenological Study, Bloomington: Indiana University Press.

Chatwin, B. (1987), The Songlines, London: Picador.

Coverley, M. (2006), Psychogeography, London: Pocket Essentials.

Crang, M. (1998) Cultural Geography, London: Routledge. 
Davidson, P. (2005) The Idea of North, London: Reaktion Books.

Dibben, N. (2006) "Subjectivity and the Construction of Emotion in the Music of Björk", Music Analysis, 25, 1-2, 171-197.

Eliezer, C. (2006) "Sigur Ros”, The Brag, 153, April 3, 17.

Elsdon, P. (2007) "Embodied listening and the music of Sigur Rós", Research Seminar at University of Cork, January.

Feld, S. (2001), "Lift-Up-Over Sounding” in David Rothenberg \& Marta Ulvaeus, (eds) The Book of Music and Nature, Middletown: Wesleyan University Press, 193206.

Feld, S. (1994) "From Ethnomusicology to Echo-Muse-Ecology: Reading R. Murray Schafer in the Papua New Guinea Rainforest", The Soundscape Newsletter, 8, June. $\quad<$ http://www.acousticecology.org/writings/echomuseecology.html $>$ (accessed 25/9/08).

Frith, S. (1996) "Music and Identity" in Stuart Hall \& Paul Du Gay (eds) Questions of Cultural Identity, London: Sage, 108-127.

Gould, G. (1967) The Idea of North, Canadian Broadcasting Corporation.

Grimley, D. M. (2006), Grieg: Music, Landscape and Norwegian Cultural Identity, Woodbridge: Boydell Press.

(2005a), Review of John Luther Adams, Winter Music: Composing the North, Music and Letters 86, 669-671.

(2005b), "Hidden Places: Hyper-realism in Björk"s Vespertine and Dancer in the Dark", Twentieth-century Music 2 (1), 37-51.

Grossberg, L. (1992) We Gotta Get out of This Place: Popular Conservatism and Postmodern Culture ,London: Routledge.

Indridason, A. (2007) The Draining Lake, translated by Bernard Scudder, London: Harvill Secker.

Jollett, Mikel (2005) "Approaching the Void with Sigur Rós" http://www.filtermag.com/index.php?c=2\&lid $=12$

Knight, D.B. (2006) Landscapes in Music:Space, Place and Time in the World'sGgreat Music, New York: rowman \& Littlefield.

Lefebvre, H. (1991), The Production of Space, Malden, MA: Blackwell.

Lundberg, D. Malm, K. \& Ronström, O. (2003) Music Media Multiculture, Landskrona: Svenskt Visarkiv.

Miller, E. D. (2003), "The Nonsensical Truth of the Falsetto Voice: Listening to Sigur Rós", Popular Musicology On Line $2<$ http://www.popular-musicology online.com/issues $/ 02 /$ miller.html $>$

Nicholson, S. (2005) Is Jazz Dead? (or has it moved to a new address), London: Routledge.

Parker, L. (2007), "Home is Where the Hvarf Is ...", 3D World, 61.

Petridis, A. (2007), "Sigur Ros, Hvarf/Heim”, The Guardian, November 2.

Reynolds, S. (1990) Blissed Out: The Raptures of Rock, London: Serpent"s Tail. 
Said, E. (1978) Orientalism, New York: Vintage.

Spirn, A. W. (1998) The Language of Landscape, London: Yale University Press.

Street, J. (1995) “(Dis)located? Rhetoric, Politics, Meaning and the Locality" in Will Straw (ed) Popular Music: Style and Identity, Centre for Research on Canadian Cultural Industries and Institutions, 255-263.

Turan, K. (2006) "Crossing the Bridge: The Sound of Istanbul", Los Angeles Times, $<18 \quad$ August.http://www.latimes.com/entertainment/news/movies/cl-etcrossing18aug18,1,1135185.story>

Tucker, M. (2007) "Northbound: ECM and "The Idea of North", in Steve Lake and Paul Griffiths (eds.) Horizons Touched: the Music of ECM, London: Granta Books.

Wainwright, R. (2002) "Women lead the way as violence sweeps jails", Sydney Morning Herald, August $14 \quad<$ Http://www.smh.com/cgibin/common/printArticle.plpath=/articles/2002/08/13/1029113929562.html (accessed 12/12/06)

Walters, J.L. (2008) “Arve Henriksen: Cartography”, The Guardian, November 28.

Webb, P. (2007) Exploring the Networked Worlds of Popular Music: Milieu Cultures, London: Routledge.

Wobble, J. (2006), Review of Psychogeography, by Merlin Coverley, The Independent, 23 July.

Young, R. "Desolation Angels", The Wire 203, January 2003, 28-33.

Zuel, B. (2005a) "Weather or not, they"re cool", Sydney Morning Herald July 30-31, 38.

(2005b), “Sigur Rós”, Sydney Morning Herald, August 6.

\section{Discography}

Björk, Vespertine, One Little Indian, 2002.

Jan Garbarek, Dis, ECM 1977.

Johan Hedin, Angel Archipelago, Atrium/Warner Music Sweden, 1998.

Arve Henriksen: Cartography, ECM Recordings, Munich, 2008.

Terje Isungset, Iceman Is, Jazzland Recordings, Norway, 2002.

Sigur Rós, með suð i eyrum við spilum endalaust, EMI, 2008.

Sigur Rós, Heima, EMI DVD, 2007.

Sigur Rós, takk... EMI, 2005.

Sigur Rós, ( ) EMI, 2002.

Sigur Rós, ágaetis byrjun, Fat Cat Records, London, 2001.

Sigur Rós, Von (1997) One Little Indian, 2004. 